\author{
Hanna Zalewska-Jura (iD \\ Uniwersytet Łódzki \\ hanna.zalewska@uni.lodz.pl
}

\title{
Sekret Chloris, czyli o greckich antroponimach w Pieśniach Horacego
}

Cechę dystynktywną łacińskiej poesis docta, której najwybitniejszym przedstawicielem był Horacy, stanowiło nawiązywanie do szeroko pojmowanej kultury greckiej. Miarą erudycji poety, znajdującej odzwierciedlenie w utworach, była znajomość języka i oczytanie w literaturze greckiej. Hellenica obecne w twórczości Horacego występują najczęściej na poziomie aluzji lub stonowanych napomknień. Poesis docta wszak adresowana była do odbiorcy elitarnego, wykształconego i wyrafinowanego, zdolnego dostrzec i rozszyfrować sensy ukryte w podtekstach. Specyficzną płaszczyznę odniesień do języka greckiego w poezji Horacego stanowią antroponimy, które, jak można przypuszczać, funkcjonują na zasadzie pseudonimów literackich. Zapoczątkowany przez „neoteryków” na gruncie liryki łacińskiej zabieg obdarzania autentycznych postaci fikcyjnymi imionami nawiązującymi do tradycji greckiej Horacy stosował z dużym powodzeniem, wzbogacając wymowę utworu o dodatkowy walor zawartej aluzji.

Owe horacjańskie antroponimy, jako element tzw. trzeciej kultury zewnętrznej wobec łaciny i polszczyzny, stanowią interesujące zagadnienie traduktologiczne, któremu poświęcone są poniższe obserwacje. Warto 
w tym miejscu wtrącić uwagę, że na gruncie zagranicznej literatury przedmiotu ten problem doczekał się już cennych opracowań na płaszczyźnie ujęć teoretycznych [Salmon Kovarski 1997: 67-83] oraz szczegółowych odniesień do imion własnych u Horacego [Carruba i Fratantuono 2003: 133-136; Lieberg 1991: 693-705].

Po dokonaniu klasyfikacji pod względem formalnym imion własnych pochodzących z greki przeprowadzona zostanie ich kontekstualna analiza semantyczna. Następnie odniesiemy się do uznanych interpretacji translatorskich i zastanowimy nad innymi możliwymi rozwiązaniami. Rozważania oprzemy na zbiorze czterech ksiąg Pieśni Horacego w przekonaniu, że dostarczają one wyczerpującego i reprezentatywnego materiału badawczego.

Warto na wstępie zaznaczyć, że starogreckie nomina propria zasadniczo, a imiona osobowe w szczególności, należą do kategorii znaczeniowo nacechowanych, nawet jeśli dzisiaj niektóre z nich wymykają się jednoznacznemu rozszyfrowaniu etymologicznemu.

Najliczniej reprezentowane greckie antroponimy u Horacego, które odnoszą się do powszechnie znanych postaci - poetów archaicznych, mitycznych bohaterów - pozostaną poza kręgiem naszego zainteresowania ze względu na ich utrwaloną obecność w kulturze polskiej i powszechne stosowanie w ich przypadku techniki tłumaczeniowej. Jest to najczęściej transfer lub transfer z modyfikacją adaptacyjną [Hejwowski 2012: 19]. Ograniczymy się zatem do tych imion, które można uznać za efekt inwencji lub zamierzeń adaptacyjnych poety.

Klasyfikację otwierają nomina, które pozostają w związku z nazwami geograficznymi, przypuszczalnie sugerując pochodzenie osoby obdarzonej pseudonimem: Lidia (łac. Lydia) - „ta, która pochodzi z Lidii, Lidyjka” (pieśni I, 8; I, 13; I, 25; II, 11; III, 9; III, 11), Licydas (łac. Lycidas) - ,ten, który pochodzi z Licji, Licyjczyk” (pieśń I, 4), Lika (łac. Lyca) - „Licyjka" (pieśni III, 10; IV, 13). W rodzaju antroponimu kryje się jednakowoż cenna informacja obyczajowa: Rzymianie bardzo często nazywali swoich niewolników od kraju ich pochodzenia. Stąd też możemy domyślać się przynależności społecznej wymienionych postaci do warstwy niewolników lub wyzwoleńców. Należy zaznaczyć erotyczny (hedonistyczny w przypadku pieśni II, 11) charakter wskazanych utworów, które przy uwzględnieniu realiów obyczajowych łatwiej interpretować w kategoriach 
pewnej konwencji miłosnego żartu i uczuciowych igraszek [Wójcik 1986: 155-156].

Drugą grupę antroponimów stanowią te, w których odbijają się echa greckiej tradycji literackiej. Imię Neobule (pieśń III, 12) przywodzi na myśl biografię Archilocha, greckiego poety, którego twórczością inspirował się Horacy. Wedle antycznej tradycji Archiloch miał zabiegać o rękę pięknej Neobule. Zaręczyny młodych zostały jednak zerwane za sprawą ojca dziewczyny, Lykambesa. Zawiedziony i rozgoryczony poeta zemścił się, bezlitośnie wyszydzając w złośliwych jambach rzekomą rozwiązłość narzeczonej i umysłową ograniczoność jej ojca. Legenda głosi, że oboje, publicznie ośmieszeni, popełnili samobójstwo. W wersji Horacego Neobule, liryczne ego utworu, jest skontrastowana z wizerunkiem, jaki wyłania się z jambów Archilocha. Oto zajęta monotonną pracą przy krosnach, tęsknie spogląda w kierunku pięknego chłopca, ale, pełna obaw o gniew surowego stryja, nie ma szans na kontakt z obiektem zainteresowania. Nie bez znaczenia dla wymowy pieśni jest analogia do ludowej proweniencji liryku Alkajosa [Page 1968: fr. 10], w której podmiot liryczny jest również zdecydowanie różny od autora. Brak odniesienia do Archilocha i Alkajosa sprawia, że lamenty Horacjańskiej Neobule odczytać można wyłącznie jako stylizację na naiwność i egzaltację młodej dziewczyny [Wójcik 1986: 152], a wymowa ody pozbawiona jest walorów uczoności.

Zdublowaną aluzję onomastyczną przynosi pieśń I, 13, gdzie podmiot liryczny daje upust zazdrości o uczucia dziewczyny (prawdopodobnie hetery), która obdarza względami młodego chłopaka, Telefa (łac. Tēlephus). Greckie pochodzenie imienia pozwala rozumieć je jako „ten, który z daleka roztacza blask", co, przez podkreślenie niezwykłej urody młodzieńca, intensyfikuje skierowaną do niego niechęć lirycznego ,ja”. Z drugiej strony w tradycji mitycznej i literackiej (Iliada Homera) imię Telephos nosił jeden z synów Heraklesa, bohater wojny trojańskiej, czyli osoba niepospolita ze względu na pochodzenie i zalety osobiste. Pod literackim pseudonimem Telephus w erotyku Horacego kryje się postać autentyczna, może to być, niemożliwy dziś do zidentyfikowania, syn jakiegoś ówczesnego rzymskiego notabla, osoba $\mathrm{z}$ różnych względów nietuzinkowa. $\mathrm{W}$ ten sposób doprecyzowana postać konkurenta zmienia perspektywę żalów lekceważonego rywala Telefa.

W trzeciej grupie klasyfikowanych antroponimów znajdują się takie, które są wyraźnym efektem ,aktu nazwotwórczego" [Jakus-Borkowa 1987: 14] poety, a ich semantyczne nacechowanie rzutuje na interpretację 
utworów, lub ich fragmentów, ze zróżnicowanym natężeniem. Dla przykładu, nie wzbogaca warstwy aluzyjnej kilkakrotnie przywoływane imię Glycera, które wywodząc się od greckiego przymiotnika glykys -,słodki”, oznacza „Słodziutka”, co w kontekście liryki miłosnej i pochwały wdzięku dziewczyny uznać należy za topos (pieśni I, 19; I, 30; I, 33). Podobnie rzecz się przedstawia z pseudonimem Lalage - „Szczebiotka”, którego morfologia wiąże się z czasownikiem lalein - „gadać, paplać, szczebiotać” (pieśni I, 22; II, 5). Na wiek dziewczyny wskazuje nomen Chloe, które jest kalką greckiego rzeczownika he kchloe - ,pierwszy zielony kiełek rośliny, młoda zieleń" (pieśń III, 9). Młodziutka Chloe stanowi w utworze kontrapunkt dla dojrzałej hetery, z którą podmiot liryczny droczy się w miłosnej wymianie zdań, wzbudzając u niej zazdrość wzmianką o młodszej rywalce. Do wyglądu zapewne odnoszą się pseudonimy: Foloe (łac. Pholoe), który pozostaje w związku etymologicznym z rzeczownikiem he pholis - „cętka na skórze" i nie znamionuje nic więcej ponad piegowatą karnację (pieśni I, 33; II, 5), oraz Pyrrus (łac. Pyrrhus), pochodzący od przymiotnika pyrros - „ognisty, o ognistej barwie” i informujący o rudym kolorze włosów chłopaka (pieśń III, 20). Jak wynika z treści ody, Rudzielec Pyrrus ma małe szanse w walce o względy pięknego chłopca, Nearcha, w konfrontacji z zafascynowaną nim dziewczyną i grupą jego młodych wielbicieli płci męskiej. Warto zauważyć, że imię Nearch (łac. Nearchus) etymologicznie stanowi zbitkę przymiotnika neos, tj. „młody”, i rdzenia arch(e)-, który oznacza między innymi „bycie pierwszym, kierowanie, przewodzenie". Imię chłopaka może wskazywać zatem na jego dominującą pozycję w gronie rówieśników, uzasadniając powodzenie, jakim cieszy się u przedstawicieli obojga płci. Seksualny podtekst przynosi imię Myrtale, którym poeta obdarza pewną heterę, wyzwoloną niewolnicę (pieśń I, 33). Imię to, nieobce tradycji greckiej, wykazuje związek z rzeczownikiem to myrton - ,jagoda mirtu, mirt”, ale również, jako anatomiczny eufemizm, znaczy „łechtaczka” [Aristophane 1928: w. 1004].

W kilku przypadkach nacechowanie antroponimów może determinować interpretację pieśni. Z taką sytuacją stykamy się w przypadku pseudonimu Chloris w odzie III, 15. Adresatką jest podstarzała kobieta, której, w ocenie narratora, ,raczej bliżej do grobu” (w. 4) niż do zabaw w gronie młodych dziewcząt i która, zamiast zachowywać się jak własna córka, powinna spędzać czas przy kołowrotku. Złośliwy ton utworu potęguje sens imienia Chloris, które wywodzi się od przymiotnika kchloros - ,zielonkawo-żółty, wyblakły”, ale również „kwitnący, młodzieńczy”. Wybór wyrazu 
wydaje się nieprzypadkowy: taka dychotomia semantyczna z jednej strony podkreśla wiek bohaterki przez skojarzenie z barwą więdnącej zieleni, $\mathrm{z}$ drugiej natomiast odnosi się do braku krytycyzmu Chloris wobec siebie i jej złudnego poczucia, że jest ciągle młoda. Warto w tym miejscu wspomnieć, że w innym utworze takim samym imieniem została obdarzona młoda dziewczyna (pieśń II, 5).

Tytułowana Do Leukonoe należy do najczęściej tłumaczonych pieśni Horacego ze względu na sławne hasło „carpe diem” (pieśń I, 11). Podmiot liryczny udziela Leukonoe życiowych rad: nie szukaj w babilońskich kabałach odpowiedzi, jaki nas czeka koniec, ile życia jeszcze nam zostało, zachowaj rozsądek, zajmij się konkretnym działaniem, nie trać czasu, chwytaj dzień [Kaczyński 2005: 178-181]. Wskazówki te formułowane są wyraźnie z pozycji człowieka dojrzałego, mądrego życiowym doświadczeniem. O umysłowości Leukonoe świadczy natomiast fakt, że szuka ona we wróżbach odpowiedzi na pytania egzystencjalne. Symboliczny sens jej imienia pogłębia intelektualny dystans między lirycznym ego a adresatką jego wypowiedzi; przymiotnik leukos - „biały” i rzeczownik ho nus „rozum, umysł”, tworzące antroponim, znamionują naiwność, żeby nie powiedzieć: infantylność dziewczyny.

Adresatem jednej z najlepiej znanych pieśni Horacego (I, 9, Vides ut alta stet), nota bene również inspirowanej pieśnią Alkajosa [Page 1968: fr. 338], jest Taliarch (łac. Thaliarchus). Utwór zyskał popularność dzięki pięknemu opisowi zimowego górskiego pejzażu. Obraz ten wypełnia pierwszą strofę. Druga przynosi wezwanie do Taliarcha, by dorzucił drew do kominka i przyniósł z amfory wyborne wino sabińskie. Stworzona $\mathrm{w}$ ten sposób atmosfera beztroski, skontrastowana $\mathrm{z}$ zamiecią $\mathrm{i}$ wichurą za oknem, stanowi tło dla, utrzymanych w duchu epikurejskim, wskazówek lirycznego ,ja" skierowanych do Taliarcha: nie troszcz się o to, co przyniesie jutro, ciesz się młodością, używaj życia, spotykaj się z rówieśnikami, raduj towarzystwem dziewcząt. Te rady wypełniają trzy ostatnie strofy. Czytelne są liryczny zimowy opis przyrody i bezdyskusyjne przesłanie utworu. Rozszyfrowanie imienia adresata ody może jednak nieco przesunąć perspektywę jej odczytania. Znaczeniowo grecki zrost thali-archos odpowiada naszemu ,podczaszy” (łac. magister bibendi). Co więcej, wzmiankowany wcześniej słowotwórczy element -arch(os) służy w grece do budowania nazw ważnych urzędników wojskowych lub cywilnych, podkreślając ich rangę i dostojeństwo. Mamy zatem w przypadku pieśni Horacego do czynienia z pewnym paradoksem: młodemu 
chłopakowi, może niewolnikowi, wyzwoleńcowi lub służącemu, nadany został pseudonim znamionujący powagę i godność. Można zatem odnieść wrażenie subtelnego żartu, a przynajmniej ,perskiego oka” ze strony poety.

Żaden ze starożytnych autorów nie doczekał się tylu przekładów na język polski co Horacy. Ich twórcami byli filologowie i poeci. Ważna w tym kontekście jest uwaga jednego z nich, Stefana Gołębiowskiego, który podjął się przełożenia na język polski całej spuścizny Horacego: „W przekładach filologicznych Horacy ginął przez wierność, w poetyckich przez niewierność, w przekładach nowatorskich wychodził udziwniony i niepodobny do siebie" [1980: 31]. Literaci w zmaganiach translatorskich dawali z jednej strony upust fascynacji pięknem łacińskich oryginałów, z drugiej - własnemu talentowi. Talentowi niebagatelnemu, o czym świadczą wybitne nazwiska, żeby przywołać kilka: Adam Asnyk, Józef Birkenmajer, Krzysztof Kamil Baczyński, Adam Ważyk, Julian Tuwim [Arndt 2016: 35-46]. Charakter artystycznego wyzwania powodował nieuchronną stronniczość wyborów i decyzji, które elementy horacjańskich utworów zachować, z których rezygnować [Jarniewicz 2015: 228-230]. Można $\mathrm{z}$ dużą dozą prawdopodobieństwa założyć, że poetyckie przekłady były raczej ,zorientowane na źródło”, czyli na tekst oryginalny, a nie na cel, czyli adresatów thumaczenia [Tabakowska 2008: 192]. Poeci-tłumacze, przyjmując postawę drugiego autora [Jarniewicz 2015: 237], nie tylko dokonywali uzasadnionych, $\mathrm{z}$ własnej perspektywy, modyfikacji oryginału [Bibik 2018: 97], ale również filtrowali te jego elementy kulturowe [Katan 2009: 75-76; Hejwowski 2004: 71-72], dla których nie znalazło się miejsce w ich interpretacji albo które uznali za niekonieczne. Do takich elementów należą właśnie antroponimy greckiego pochodzenia.

Niepodobna w ramach artykułu przywołać wszystkich tłumaczeń wymienionych utworów. Byłby to zresztą zabieg bezcelowy, ponieważ, przy założeniu marginesu nieścisłości, bez trudu można wskazać dominującą technikę: jest nią transfer, czyli przeniesienie antroponimu do tekstu przekładu. Sporadycznie transfer połączony jest $\mathrm{z}$ fonetyczną adaptacją, na przykład Lidia w miejsce Lydia, Lika zamiast Lyca i Licydas zamiast Lycidas, Taliarch w miejsce Thaliarchus, a Nerach zamiast Nearchus. Za ewenement można uznać imię Lalage, które oddawane bywało jako „Szczebiotka” w wersjach Birkenmajera i Lama. Jan Czubek natomiast posłużył się rzeczownikiem „,szczebiotka” w funkcji przydawki do Lalage. 
Ci przedwojenni czytelnicy przekładu Czubka, którzy wyposażeni byli w kompetencje językowe, mogli wychwycić niezbyt zręczny efekt tautologii - Szczebiotka, która szczebiocze. Dla pozostałych odbiorców sens imienia Lalage pozostał niewiadomą. Do unikatowych rozwiązań należy opuszczenie antroponimu, z czym mamy do czynienia w przypadku tłumaczenia Henryka Sienkiewicza pieśni Do Leukonoe (I, 11). Warto przytoczyć ten przekład in extenso celem ukazania osiągniętego efektu:

Nie pytaj próżno, bo nikt się nie dowie,

Jaki nam koniec szykują bogowie,

I babilońskich nie pytaj wróżbiarzy.

Lepiej tak przyjąć wszystko, jak się zdarzy.

A czy z rozkazu Jowisza ta zima,

Co teraz wichrem wełny morskie wzdyma,

Będzie ostatnia, czy też nam przysporzy

Lat jeszcze kilka tajny wyrok boży,

Nie troszcz się o to i... klaruj swe wina.

Mknie rok za rokiem, jak jedna godzina.

Więc łap dzień każdy, a nie wierz ni trochę

W złudne przyszłości obietnice płoche.

[Horacy 1967]

Dla porównania niezbędne jest przywołanie tłumaczenia Zygmunta Kubiaka, najbliższe oryginałowi:

Nie pytaj, nie godzi się wiedzieć, jaki mnie, jaki tobie

Bogowie kres przeznaczyli, o Leukonoe! Nie szukaj

Wróżb babilońskich. O ileż lepiej: co będzie, przyjmować.

Czy więcej zim da nam Jowisz, czy to już dla nas ostatnia

$\mathrm{Na}$ ostrych skałach wybrzeża rozbija fale tyrreńskie,

Bądź mądra, przecedzaj wino, a krótką miarą powściągaj

Długie nadzieje. Gdy rozmawiamy tak, czas już przemknął

Zazdrosny. Każdy dzień zrywaj, ani trochę nie wierząc jutru.

[Kubiak 1999: 469]

Sienkiewicz rezygnuje z określenia adresata wskazówek formułowanych przez ,ja” liryczne. Dzięki temu wymowa utworu nabiera uniwersalnego charakteru. Temu samemu celowi może służyć pominięcie aluzji geograficznej: nie ma już mowy o Morzu Tyrreńskim, czyli o zachodnich wybrzeżach Półwyspu Apenińskiego. Miejsce akcji jest nieokreślone. Na 
trop czasu akcji prowadzi jedynie postać Jowisza - starożytnego bóstwa, które zawiaduje zjawiskami atmosferycznymi, ale nie decyduje o przyszłości i długości życia ludzkiego. Tę określa „wyrok boży”. Jeśli aluzję mityczną potraktować w kategoriach środka wyrazu artystycznego, wersja Sienkiewicza ma wymiar ponadczasowy. Nie podważa go nawet wzmianka o „babilońskich wróżbiarzach”, ponieważ symbolizują oni wiedzę chaldejskich astronomów, od niepamiętnych czasów uznawanych za niedoścignionych w tej materii. Odbiorcą życiowych rad zawartych w utworze może być każdy, zawsze i wszędzie. Uniwersalne przesłanie pieśni w thumaczeniu Sienkiewicza tworzy nastrój powagi. Tę jednak burzy forma: dwanaście regularnych sześciozgłoskowców wypełnionych krótkimi zdaniami daje pogodny efekt. Także metrum zastosowane w oryginale - wiersz asklepiadejski większy - nie buduje nastrojowego klimatu, przeciwnie, szybkie tempo - uzyskane dzięki choriambom i dwóm dierezom - skutkuje lekkością. U Horacego pogodny ton wynika nie tyle $\mathrm{z}$ treści rad udzielanych naiwnej dziewczynie, ile z planu sytuacyjnego rozmowy z młodziutką interlokutorką i relacji, jakie zachodzą między nią a podmiotem lirycznym. Ten nie przemawia do Leukonoe z pozycji mędrca i mentora, ale z perspektywy, jak wcześniej zauważono, mądrego doświadczeniem życiowym dojrzałego mężczyzny, na którego ustach być może błąka się uśmiech pobłażania. Sienkiewicz wyraźnie znalazł własny klucz do odczytania „całokształtu sensów” [Barańczak 1990: 37] pieśni Horacego. Kubiak natomiast usiłował oddać oryginał w sposób jak najbardziej wierny, nawet w formie, znajdując dla wiersza asklepiadejskiego większego odpowiednik w regularnym szesnastozgłoskowcu. Jego brzmienie jednak, dalekie od lekkości łacińskiego wiersza, zdaje się podkreślać nastrojowość pieśni.

Dzisiejszy odbiorca przekładów pieśni Horacego, poszukujący doznań estetycznych, ma do dyspozycji szeroki wachlarz artystycznie opracowanych wersji, z których każda jest subiektywną interpretacją tłumacza-poety [Bednarczyk 2008: 13-17], przy czym wszystkie są wartościowe ze względu na różnorodność ujęć. Trudno jednak nie zgodzić się z poglądem, że „oryginały się nie starzeją, przekłady tak” [Bibik 2018: 97]. Owo starzenie wynika po części ze zmienności norm translatorycznych [Jarniewicz 2015: 246-247], po części zaś z odmiennych uwarunkowań społecznych i zmieniającego się profilu docelowego odbiorcy. Jeszcze w latach 60. ubiegłego 
wieku poziom znajomości języka łacińskiego wśród czytelników zainteresowanych poezją umożliwiał samodzielną lekturę oryginalnych tekstów. Odbiorca nie spodziewał się od przekładu pełni Horacjańskich sensów, bo te mógł odkrywać sam, na ile pozwalały mu kompetencje językowe w zakresie łaciny (i greki). Tłumacz natomiast nie czuł się zobligowany odkrywać obecne w oryginale aluzje i podteksty, nawet jeśli był ich świadomy, zwłaszcza w przypadku greckich kulturemów.

Na przestrzeni ostatnich dziesięcioleci znaczącej redukcji uległa znajomość języka łacińskiego, czego konsekwencją mogą być odmienne oczekiwania pewnej grupy czytelników przekładów. Chodzi o tę grupę, która nie mając narzędzi lingwistycznych, chce jak najbardziej zbliżyć się do treści oryginału, aby dokonać własnej interpretacji i na jej podstawie odsłonić rozmaite niuanse. Przekłady, które znajdują się w obiegu, nie stwarzają takiej możliwości. Można nawet odnieść wrażenie, że ich autorzy w ogóle nie projektowali typu adresata, a jeśli już, to z pułapu wyższości - na zasadzie ,ja wiem, ale wy nie musicie wiedzieć" [Hejwowski 2004: 59]. Należy przy tym podkreślić elitarność czytelników poezji Horacego w Polsce. Nie są to bierni odbiorcy, ale aktywni uczestnicy procesów rozumienia, gotowi do wysiłku intelektualnego i dociekania ukrytych sensów. Konieczna jest jednak świadomość, że te ukryte sensy w tekście w ogóle istnieją. $\mathrm{Na}$ jakich bowiem przesłankach ma czytelnik powziąć podejrzenie, że imię, z którym styka się w konkretnej pieśni Horacego, ma grecką proweniencję, a później, że ma charakter intencjonalny? Bez tego rozszyfrowanie jego zawartości znaczeniowej jest nieosiągalne. Dostrzeżenie ukrytego w nim sensu - niemożliwe.

Jedyną drogą zbliżenia się do zamysłów rzymskiego poety są informacje zawarte w przekładach jego pieśni. Fakt, że mamy do czynienia $\mathrm{z}$ utworem poetyckim oraz że omawiane antroponimy pochodzą z języka zewnętrznego wobec języka oryginału, wydatnie komplikuje i redukuje rozwiązania translatorskie. W jednostkowych przypadkach zaledwie można wyjść poza zabieg reprodukcji (transferu) i to przy założeniu osiągnięcia efektu ,udomowienia”. Efektu, dla którego, podkreślmy, w oryginale Horacego nie ma miejsca, gdyż zamiarem poety było wprowadzenie elementów greckich, czyli obcych dla języka łacińskiego, zgodnie z programowymi założeniami poesis docta. Istnieje zatem teoretycznie możliwość posiłkowania się w polskim tłumaczeniu hiperonimami, na przykład: „Słodziutka” dla Glycera, „Pieguska” dla Foloe, „Szczebiotka” dla Lalage i „Rudzielec” dla Pyrrusa. Barierą może się jednak okazać kontekst, w który nie zawsze 
hiperonim się wpisuje. Stosowny przykład przynosi wspomniana wcześniej pieśn III, 20, w której Pyrrus zabiega o względy urodziwego chłopaka Nearcha. O ile imię Pyrrus można spolszczyć za pomocą hiperonimu, o tyle w przypadku nomen proprium Nearchus stanowi to poważny problem. „Przetłumaczenie” jednego imienia, przy jednoczesnym pozostawieniu drugiego w oryginalnym brzmieniu, jest nie do przyjęcia. Tłumacz może również uciec się do utworzenia neologizmu strukturalnego [Kurkowska i Skorupka 1964: 71], biorąc pod uwagę, że tym środkiem wyrazu niejednokrotnie posługuje się łaciński poeta w tworzeniu pseudonimów. Tu jednak kryje się lingwistyczna pułapka, która wynika ze specyfiki greki, języka „podatnego” na tworzenie czytelnych złożeń morfologicznych. Przed podjęciem próby takiego rozwiązania warto wyciągnąć wniosek $\mathrm{z}$ faktu, że poeci tłumaczący Horacego niechętnie ulegali takiej pokusie. Inna możliwa technika translatorska w postaci zastosowania apelatywu (dziewczyna, chłopak) w miejsce konkretnego antroponimu zniweczy jego wartość intencjonalną i nie spełni oczekiwań aktywnego intelektualnie czytelnika przekładu.

Przy uwzględnieniu nakreślonego wcześniej typu docelowego odbiorcy oraz wobec zastrzeżeń do przedstawionych wyżej rozwiązań translatorskich za optymalny uznać należy transfer, któremu musi towarzyszyć przypis z precyzyjną informacją o etymologii i znaczeniu imienia „mówiącego". Czytelnik wyposażony w takie narzędzie poznawcze ma szanse sam odsłonić ukryte w antroponimie kontekstualne sensy, bez względu na to, czy przekład, w który się zagłębi, będzie miał charakter literacki, czy filologiczny.

Wątpliwości wobec stosowania zaproponowanej procedury mogą powstać na gruncie poglądu o jej niskiej wartości. Sformułowana przed wielu laty przez Olgierda Wojtasiewicza opinia: „Objaśnienia można wprowadzić różnymi sposobami. Najprymitywniejszym będzie przypis, zręczniejszym zaś będzie wplecenie jakiegoś króciutkiego komentarza w sam tekst przekładu" [1957: 78], ma wielu zwolenników. Żaden tłumacz nie chce, aby jego starania o umożliwienie czytelnikowi rozkodowania pewnych niuansów obecnych w oryginalnym utworze były oceniane w kategoriach translatorskiej nieudolności i porażki czy wręcz postrzegane jako „narośl na subtelnej tkance stylu i narracji" [Hrehorowicz 1997: 111]. Zwłaszcza thumacz utworów starożytnych, który ze względu na chronologiczną odległość tekstów inaczej widzi swoją rolę pośrednika między autorem a czytelnikiem. Zachowując niewidoczną postawę lub przynajmniej pozostając 
w cieniu autora, taki tłumacz nie może być całkowicie pozbawiony głosu [Stróżyński 2009: 49] właśnie po to, by głos twórcy oryginału był zrozumiały. Ewa Skwara, filolog klasyczny i jednocześnie tłumaczka łacińskich komedii Plauta i Terencjusza, polemizując z krytyką ingerencji w tekst w formie przypisów, zauważyła: „Ta zasada nie obowiązuje jednak w przekładach dzieł antycznych oraz utworów uznanych za zabytki literatury tak odległej epoki, że wymagają gruntownego zaplecza krytyczno-literackiego, aby ich wartość mogła być w pełni doceniona" [2004: 263]. Prosta konstatacja, że informacja zawarta w przypisie ma za zadanie wyrównać różnicę między tłumaczem a czytelnikiem przekładu [Sztorc 2019: 29], nie powinna zostawiać wiele miejsca na polemikę.

Tłumaczenia dzieł starożytnych nie przybywają lawinowo. Rodzi to niejednokrotnie potrzebę sięgania do istniejącego już repertuaru przekładów. W przypadku Pieśni Horacego jest on wyjątkowo bogaty. Mimo to nie realizuje, jak wspomniano, potrzeb i oczekiwań wszystkich typów odbiorców. Stąd uzasadniony jest postulat pod adresem redaktorów i wydawców planujących reedycje Horacjańskich zbiorów lub wyborów, aby zrewidowali niechęć do przypisów w przekładach literatury pięknej i wzięli na siebie ciężar wzbogacenia ich o niezbędne komentarze [Bednarska i Szafraniec 2017: 205-206]. Za rodzaj egzemplifikacji uznać można bilingwiczne wydanie Dziet wszystkich Horacego pod redakcją Oktawiusza Jurewicza z 1986 (tom I) i 1988 (tom II) roku. Jurewicz zaprojektował odbiorców z grona osób, które próbują zmierzyć się z oryginalnym tekstem. Każdy łaciński utwór opatrzony jest komentarzem metrycznym, a w formie przypisów licznymi uwagami językowymi i kulturowymi. Wśród nich znajdują się także informacje odnośnie do omawianych antroponimów. Niestety, niejednokrotnie bardzo pobieżne, gdy ograniczają się do sformułowań: „imię pochodzenia greckiego" lub „imię mówiące pochodzenia greckiego”. Zdarza się również, że podane znaczenie nie może ostać się bez zastrzeżeń, jak na przykład w przypadku Leukonoe, której imię rozszyfrowano jako „pogodna, radosna” [Horacy 1986: 89]. Ogromną zaletą tej publikacji jest jednak imponujący zbiór tłumaczeń, które pochodzą z różnych epok i obrazują rozmaite ,poetyki przekładu”. Niezależnie od jej mankamentów, które po części wynikają z koncepcji redaktorskiej, jest to z pewnością krok w dobrym kierunku dla realizacji końcowego postulatu. 


\section{Bibliografia}

Aristophane (1928), Lysistrata, t. 3 (oprac. Victor Coulon i Hilaire van Daele), Les Belles Lettres, Paris.

Arndt, A. (2016), „Antyk u Tuwima”, [w:] W. Stroh, Łacina umarła, niech żyje łacina! Mała historia wielkiego języka (tłum. Aleksandra Arndt), Wydawnictwo Poznańskiego Towarzystwa Przyjaciół Nauk, Poznań, 23-48.

Barańczak, S. (1990), „Mały, lecz maksymalistyczny Manifest translatologiczny albo: Tłumaczenie się z tego, że thumaczy się wiersze również w celu wytłumaczenia się innym tłumaczom, iż dla większości tłumaczeń wierszy nie ma wythumaczenia", Teksty Drugie. 3: 7-66.

Bednarczyk, A. (2008), W poszukiwaniu dominanty translatorskiej, Wydawnictwo Naukowe PWN, Warszawa.

Bednarska, K., Szafraniec, K. (2017), „Przypisy thumacza w wybranych słoweńskich przekładach literatury polskiej”, Przeklady Literatur Stowiańskich. 8(1): 205-217.

Bibik, B. (2018), „(Nie)typowa rola tłumacza starożytnych tekstów dramatycznych", Między Oryginatem a Przektadem. 1(39): 89-102, https://doi. org/10.12797/MOaP.24.2018.39.06.

Carruba, R. W., Fratantuono, L. M. (2003), „Apollo and Leuconoe in Horace, Odes I, II", Quaderni Urbinati di Cultura Classica. 74(2): 133-136, https:// doi.org/10.2307/20546778.

Hejwowski, K. (2004), Kognitywno-komunikacyjna teoria przekładu, Wydawnictwo Naukowe PWN, Warszawa.

Hejwowski, K. (2012), „Nazwy własne w tekście literackim - techniki thumaczenia", [w:] Roman Lewicki, red. Przekład. Język. Kultura, t. 3, Wydawnictwo Uniwersytetu Marii Curie- Skłodowskiej, Lublin, 11-22.

Horacy (1980), Dzieła (tłum. Stefan Gołębiowski), Ludowa Spółdzielnia Wydawnicza, Warszawa.

Horacy (2010), Dzieła wszystkie, Otto Vaenius, Emblematy horacjańskie (thum. Andrzej Lam), Oficyna Wydawnicza ASPRA, Pułtusk-Warszawa.

Horacy (1967), Wybór poezji (oprac. Jerzy Krókowski), Zakład Narodowy im. Ossolińskich, Wrocław.

Horatius Flaccus, Quintus (1924), Poezje. Pieśni, jamby, satyry, listy (tłum. Jan Czubek), Gebethner i Wolff, Warszawa.

Horatius Flaccus, Quintus (1935), Wybór poezji, Filomata, Lwów.

Hrehorowicz, U. (1997), „Przypisy thumacza: «to be or not to be»”, Między Oryginatem a Przektadem. 3: 109-116. 
Jakus-Borkowa, E. (1987), Nazewnictwo polskie, Wydawnictwo WSP, Opole.

Jarniewicz, J. (2015), „Literary Translation”, [w:] Łukasz Bogucki, Stanisław Goźdź-Roszkowski, Piotr Stalmaszczyk, red. Ways to Translation, Wydawnictwo Uniwersytetu Jagiellońskiego, Wydawnictwo Uniwersytetu Łódzkiego, Kraków-Łódź, 227-248.

Kaczyński, J. R. (2005), „To, co najtrudniejsze, czyli problemy z tłumaczeniem ody «Do Leukonoe»", Meander. 60(2): 175-182.

Katan, D. (2009), „Translation as Intercultural Communication”, [w:] Jeremy Munday, red. The Routledge Companion to Translation Studies, Routledge, London, 74-92.

Kubiak, Z. (1999), Literatura Greków i Rzymian, Wydawnictwo Świat Książki, Warszawa.

Kurkowska, H., Skorupka, S. (1964), Stylistyka polska. Zarys, Państwowe Wydawnictwo Naukowe, Warszawa.

Kwintus Horacjusz Flakkus (1986), Dzieła wszystkie, t. 1: Ody i epody (oprac. Oktawiusz Jurewicz), Zakład Narodowy im. Ossolińskich, Wrocław.

Lieberg, G. (1991), „Il significato del nome proprio femminile nei poeti latini specialmente in Catullo e Orazio", [w:] Studi di filologia classica in onore di Giusto Monaco, t. 2, Università di Palermo, Palermo, 693-705.

Page, D. L. (red.) (1968), Lyrica Graeca Selecta, Clarendon Press, Oxford.

Salmon Kovarski, L. (1997), „Onomastica letteraria e traduttologia: dalla teoria alla strategia", Rivista Italiana di Onomastica. 3(1): 67-83.

Skwara, E. (2004), „Tłumaczenie thumaczenia - czyli o roli przypisów do przekładu (na przykładzie «Braci» Terencjusza)", [w:] Ireneusz Mikołajczyk, red. Sapere aude. Księga pamiatkowa ofiarowana profesorowi dr. hab. Marianowi Szarmachowi z okazji 65 rocznicy urodzin, Wydawnictwo Uniwersytetu Mikołaja Kopernika, Toruń, 263-276.

Stróżyński, T. (2009), „Przypisy Boya tłumacza”, [w:] Elżbieta Skibińska, red. Przypisy thumacza, Księgarnia Akademicka, Wrocław-Kraków, 49-73.

Sztorc, W. (2019), „Rozmowy między wierszami - interakcje thumacza z autorem w przypisach (i innych paratekstach) do tekstów literackich", Między Oryginatem a Przektadem. 1(43): 29-46, https://doi.org/10.12797/MOaP.25.2019.43.02.

Tabakowska, E. (2008), O przekładzie na przyktadzie. Rozprawa tlumacza z „Europa" Normana Daviesa, SIW Znak, Kraków.

Wojtasiewicz, O. (1957), Wstęp do teorii thumaczenia, Zakład Narodowy im. Ossolińskich - Wydawnictwo PAN, Wrocław.

Wójcik, A. (1986), Talent i sztuka. Rzecz o poezji Horacego, Zakład Narodowy im. Ossolińskich, Wrocław. 


\section{STRESZCZENIE}

Nurt poesis docta w Pieśniach Horacego przejawia się między innymi w sferze antroponimii o greckim źródłosłowie. Chodzi tu o pseudonimy, których semantyka nawiązuje do topografii (np. Lydia, Lycidas, Lyca), do greckiej tradycji literackiej (np. Neobule, Telephus), oraz takie, w których kryją się aluzje istotne dla odczytania sensu utworu lub jego części (np. Glycera, Lalage, Chloe, Foloe, Chloris, Myrtale, Pyrrus). W poetyckich przekładach na język polski te nacechowane znaczeniowo nomina propria nie są tłumaczone, co sprawia, że odbiorca przekładu nie ma świadomości zawartej w imieniu aluzji, a tym samym pozbawiony jest możliwości rozkodowania szerokiej gamy podtekstów. W artykule omówione zostały możliwe rozwiązania translatorskie, które mogą spełnić oczekiwania różnych grup docelowych polskich czytelników, szczególnie tych niedysponujących przygotowaniem językowym w dziedzinie języków starożytnych.

Słowa kluczowe: Pieśni Horacego, greckie antroponimy, tłumaczenie

\section{Abstract}

The Secret of Chloris. On the Greek Anthroponyms in Horace's Odes The trend of poesis docta in Horace's Odes manifests itself, inter alia, in the sphere of anthroponomy, as many of the names introduced by the poet into his works are of Greek origin. These are pseudonyms, the meaning of which refers to topography (e.g. Lydia, Lycidas, Lyca), to Greek literary tradition (e.g. Neobule, Telephus) and pseudonyms in which there are allusions essential for reading the sense of the work or its part (e.g. Glycera, Lalage, Chloe, Foloe, Chloris, Myrtale, Pyrrus). In poetic translations into Polish, these meaningful nomina propria are not translated, which means that the recipient of the translation is not conscious of the allusion hidden behind the name, and thus is deprived of the possibility of decoding a vast range of subtexts. The article discusses possible translation solutions that can meet the expectations of various target groups of Polish readers, especially those who do not have linguistic preparation in the field of ancient languages.

Keywords: Horace's Odes, Greek anthroponomy, translation 